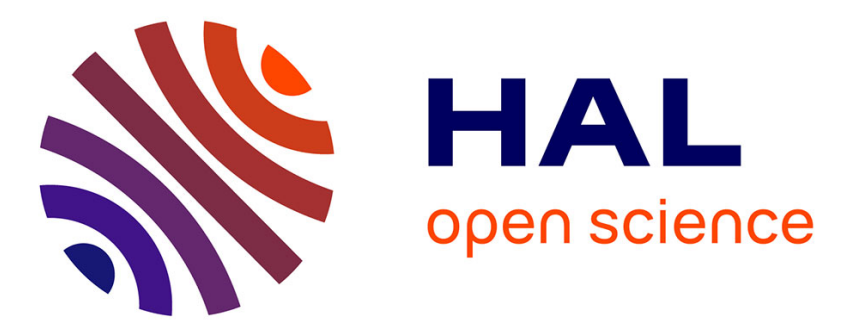

\title{
Purification of chinook salmon (Oncorhynchus tshawytscha) GH for receptor study
}

Pierre-Yves Le Bail, Geneviève Boulard, Bruno Barenton, Michel Zygmunt

\section{To cite this version:}

Pierre-Yves Le Bail, Geneviève Boulard, Bruno Barenton, Michel Zygmunt. Purification of chinook salmon (Oncorhynchus tshawytscha) GH for receptor study. Fish Physiology and Biochemistry, 1989, 7 (1-4), pp.243-251. 10.1007/BF00004713 . hal-02728107

\section{HAL Id: hal-02728107 https://hal.inrae.fr/hal-02728107}

Submitted on 2 Jun 2020

HAL is a multi-disciplinary open access archive for the deposit and dissemination of scientific research documents, whether they are published or not. The documents may come from teaching and research institutions in France or abroad, or from public or private research centers.
L'archive ouverte pluridisciplinaire HAL, est destinée au dépôt et à la diffusion de documents scientifiques de niveau recherche, publiés ou non, émanant des établissements d'enseignement et de recherche français ou étrangers, des laboratoires publics ou privés. 


\title{
Purification of chinook salmon (Oncorhynchus tshawytscha) GH for receptor study
}

\author{
Pierre-Yves Le Bail ${ }^{1}$, Geneviève Boulard ${ }^{1}$, Bruno Barenton ${ }^{2}$ and Michel Zygmunt ${ }^{3}$ \\ ${ }^{I}$ Laboratoire de Physiologie des Poissons, INRA, Campus de Beaulieu, 35042 Rennes Cedex, France; \\ ${ }^{2}$ Laboratoire de Physiologie Animale, INRA, 9 place Viala, 34060 Montpellier, France; ${ }^{3}$ Station de \\ Pathologie de la Reproduction, INRA, 37380 Nouzilly, France
}

Keywords: fish, salmon, growth hormone, biological activity, radioreceptor assay, purification techniques

\begin{abstract}
A method for the purification of chinook salmon (Oncorhynchus tshawytscha) $\mathrm{GH}$, which retains its biological activity, is described. The biological activity was investigated with an established radioreceptor assay using liver membranes from pregnant rabbits and bovine $\mathrm{GH}$ as standard and labelled hormone. The enrichment of the preparation was checked with electrophoresis (SDS-PAGE). Extraction and further steps were carried out using low molarity alkaline buffer $(\mathrm{pH} 8-10, \mathrm{M}=100 \mathrm{mM})$. Three chromatography steps were performed (Concanavalin-A sepharose, Bio-gel P60, DEAE). Ion exchange chromatography was performed under isocratic conditions (using a $50 \mathrm{~cm}$ column). Two isoforms (sGH1 and $\mathrm{sGH} 2$ ) were isolated. The purification yield is $0.7 \%$ compared to lyophilized pituitaries. The molecule is homogeneous in SDS-PAGE. Contamination by prolactin, gonadotrophin and corticotrophin is negligible $(<0.5 \%)$. It could be demonstrated that the biological activity of the preparation is maintained since this preparation stimulates the growth of juvenile trout (Salmo gairdneri) and binds specifically (35\%) to trout liver membranes.
\end{abstract}

\section{Introduction}

To date, there has been little study of the endocrine mechanisms of growth in teleost fish. The development of radioimmunoassays for fish growth hormones during the last few years (Cook et al. 1983; Wagner and McKeown 1986; Bolton et al. 1986) should enable a better understanding of this process. Knowledge of both the circulating hormone levels and the receptors of these hormones are equally important. However, among the different GH's purified (Cook et al. 1983; Famer et al. 1976; Wagner et al. 1985; Specker et al. 1985; Kawauchi et al. 1986; Kishida et al. 1987) only that from the tilapia has been used in a homologous system to demonstrate the presence of receptors (Fryer 1979). Evidence that such receptors exist in other species of fish has necessitated the use of GH heterologues such as that used for tilapia (Fryer 1979; Fryer and Bern 1979) or bovine GH (Tarpey and Nicoll 1985). The absence of homologous studies on salmonid GH may be a reflection of the fact that the isolated peptides are weakly hydrophilic; Bolton et al. (1986) found it necessary to add Triton $\times 100$ to dissolve chum salmon (Oncorhynchus keta) GH. It is possible that this hydrophobic property was acquired during their purification which involved 'harsh' techniques such as precipitation. Thus, our aim was to purify the growth hormone of the chinook salmon (O. tsawytscha) using relatively 'gentle' techniques to conserve the hydrophilic properties of the resulting $\mathrm{GH}$, properties necessary for it to bind to its receptor and to demonstrate its biological activity. 


\section{Materials and methods}

\section{Pituitaries}

Chinook salmon (O. tshawytscha) pituitary glands were collected (from adult females) at the Spring Creek hatcheries (Colombia River) of Washington State (U.S.A.) during the 1976 spawning season. They were frozen immediately in liquid nitrogen and maintained thus until lyophilisation.

\section{Isolation}

The purification protocol used was based on the method of Komourdjian and Idler (1979) with modifications. Purification took 5 days at $4^{\circ} \mathrm{C}, 1 \mathrm{~g}$ of lyophilised pituitary powder was homogenized with a Dounce homogenizer (Kontes glass C.O.) in $70 \mathrm{ml}$ of ammonium bicarbonate buffer $(100 \mathrm{mM}$, pH 10, PMSF $0.1 \%$ ) for 10 minutes. The homogenate was centrifuged at $40,000 \times \mathrm{g}$ for 45 minutes and the supernatant was retained; this step was repeated. The combined supernatants were applied to a column $(3 \times 18 \mathrm{~cm})$ of Concanavalin ASepharose (Con-A) (Pharmacia) and eluted with Tris-HCl buffer $\left(50 \mathrm{mM} \mathrm{NaCl}, 150 \mathrm{mM}, \mathrm{MgCl}_{2}\right.$ $1 \mathrm{mM}, \mathrm{CaCl}_{2} 1 \mathrm{mM}, \mathrm{MnCl}_{2} 1 \mathrm{mM}, \mathrm{pH} 7.8,20 \mathrm{ml} /$ hour). The Con-A eluent containing unbound material was concentrated to $15 \mathrm{ml}$ in an ultrafiltration cell (Amicon Diaflo, D $=76 \mathrm{~mm}$, PM 10). The sample was applied directly to a column of Bio-gel P 60 (Biorad, $5 \times 100 \mathrm{~cm}, 70 \mathrm{ml} / \mathrm{h}$ ) and eluted with ammonium bicarbonate buffer $(100 \mathrm{mM}$, $\mathrm{pH} 10$ ). The 10,000 to $30,000 \mathrm{MW}$ fraction was diluted with distilled water to $5 \mathrm{mM}$ and concentrated to $20 \mathrm{ml}$ with an ultrafiltration cell. The sample was applied to a column of DEAE Trisacryl $M$ (IBF, $1.6 \times 50 \mathrm{~cm}, 40 \mathrm{ml} / \mathrm{h}$ ) equilibrated with $500 \mathrm{ml}$ $5 \mathrm{mM}$ ammonium bicarbonate and eluted with $20 \mathrm{mM}$ buffer. The GH eluted as two peaks. Each peak was concentrated and dialyzed in $10 \mathrm{mM}$ ammonium bicarbonate with a Micro-Prodicon system (Bio-Molecular Dynamics, Prodimem PA-10), $\mathrm{GH}$, at final concentration of $0.5 \mathrm{mg} / \mathrm{ml}$, was lyophilized.

\section{Characterisation}

sGH was localized by comparison with bGH (NIH bGH B1) in SDS-PAGE electrophoresis $(6.5-16 \%$ gradient) after denaturation with 2-mercaptoethanol (Eastman Kodak Co.) for 5 minutes at $100^{\circ} \mathrm{C}$ (Laemmli 1970). Homogeneity was studied on HPLC TSK 2000 analytical column (Toyo Soda M Co., $0.75 \times 60 \mathrm{~cm})$ with phosphate buffer $(200 \mathrm{mM}$, $\mathrm{pH} 7.5,0.5 \mathrm{ml} / \mathrm{min}$ ). Immunological properties of $\mathrm{sGH}_{1}$ and $\mathrm{sGH}_{2}$ were compared by Ouchterlony's (1967) gel diffusion technique. Antibodies anti $\mathrm{SGH}_{2}(7302 \mathrm{~F})$ were obtained from New Zealand white rabbits injected intradermally with $100 \mu \mathrm{g}$ of $\mathrm{sGH}_{2}$ every two weeks for three months; $\mathrm{sGH}$ was dissolved in $20 \mu$ l of $10 \mathrm{mM} \mathrm{NaOH}$ before mixing with $1 \mathrm{ml}$ of $\mathrm{NaCl} 0.9 \%$ - Freunds adjuvent (50/50) solution. Radioimmunoassay of a solution containing $3 \mu \mathrm{g} / \mathrm{ml}$ of purified sGH were performed to estimate any contamination by SGTH (Breton et al. 1978), sPRL (Hirano et al. 1985) and ACTH (Sumpter and Donaldson 1986). For an immunocytochemical study, mature rainbow trout pituitaries were fixed in a Bouin Holland solution and serial sagittal sections $(5 \mu \mathrm{m})$ stained using the Cleveland Ricker Wolfe method (Gabe 1968). Adjacent sections were used to react with $\mathrm{sGH}$ antibody (dilution $1 / 100$ ). The peroxidase-conjugated swine immunoglobulin anti-rabbit serum (Dako) was revealed with 4-chloro-1-naphthol $(0.2 \mathrm{mg} / \mathrm{ml}$ in phosphate buffer $50 \mathrm{mM}$ ).

\section{Biological activity}

To determine the best conditions of its extraction from pituitaries, sGH activity was tested in a mammalian radioreceptor assay (Gerasimo et al. 1979). At the end of purification, sGH binding activity was tested on trout liver membranes in excess (330 $\mu \mathrm{g}$ of protein; Le Bail unpublished data) prepared using the Fryer method (1979), bGH and sGH were iodinated with ${ }^{125}$ I using the modified chloramine T method (Kelly et al. 1979). ${ }^{125}$ I labelled protein was separated from unreacted iodine by gel filtration on a ACA-54 column $(0.5 \times 20 \mathrm{~cm})$ using phosphate buffer (100mM, pH 7.5) with 


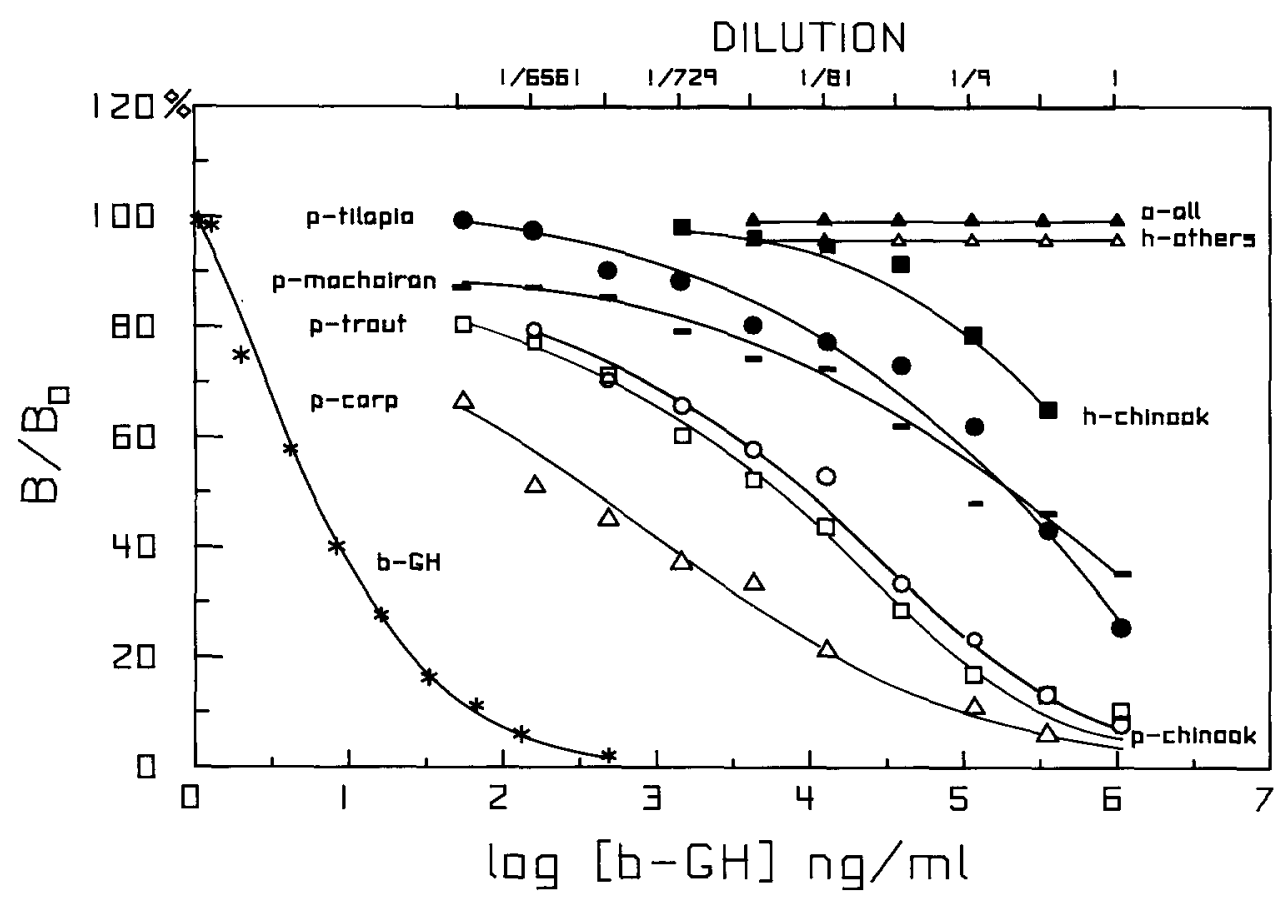

Fig. 1. Representative mammalian radioreceptorassay (RRA): dose-response inhibition curves for bovine growth hormone (bGH) and serial dilutions of crude pituitary (p), hypothalamus (h) and optic lobe (o) extracts from carp (Cyprinus carpio), rainbow trout (Salmo gairdneri), chinook salmon (Oncorhynchus tshawytscha), machoiran (Chrysichthys nigrodigitatus) and tilapia (Oreochromis niloticus). Dilution 1 corresponds to the part of brain diluted in one milliliter of buffer.

BSA $(0.5 \%)$ and $\mathrm{NaCl}(9 \%)$. The specific activity was estimated (about $60 \mu \mathrm{ci} / \mu \mathrm{g}$ ) from the rate of iodine incorporation in $\mathrm{GH}$. Liver membranes were incubated with $20,000 \mathrm{cpm}$ of $\mathrm{GH}$ for $16 \mathrm{~h}$ at $4^{\circ} \mathrm{C}$ in the same buffer. One $\mu \mathrm{g}$ of $\mathrm{GH}$ was added to determine the nonspecific binding. Bound and free hormone were separated by the addition of $3 \mathrm{ml}$ of assay buffer (Tris-HCL $20 \mathrm{mM}, \mathrm{MgCl}_{2} 10 \mathrm{mM}$, BSA $0.5 \%, \mathrm{pH} 7.5$ ) and centrifugation at $3,000 \times \mathrm{g}$ for 10 minutes. The supernatant was decanted and the ${ }^{125}$ I labelled $\mathrm{GH}$, bound to the membrane pellet, was counted in an automatic gamma counter (Packard Multi-Prias 2). Different parts of brain (optic lobes, hypothalamus and pituitary) from a range of species were extracted in $1 \mathrm{ml}$ of assay buffer. Serial dilutions of these initial extracts were tested with the mammalian radioreceptor assay. The species used were carp (Cyprinus carpio, $5 \mathrm{~kg}$ ), rainbow trout (Salmo gairdneri, $2 \mathrm{~kg}$ ), chinook salmon (O. tshawytscha), machoiran (Chrysichthys nigrodigitatus, $100 \mathrm{~g}$ ), and tilapia (Oreochromis niloticus, $150 \mathrm{~g}$ ).
A trout bioassay was performed on intact juvenile $1+$ rainbow trout $(21.48 \pm 11.00 \mathrm{~g}, \mathrm{~N}=$ 27). The 3 groups of 9 fish, distinguished with different Alcian Blue spots (Societé chimique Pointed Girard S.A.), were maintained in the same tank $(300 \mathrm{l})$ at $13^{\circ} \mathrm{C}$ for the duration of the experiment. Fish were fed ad libitum with pellets (Aqualim). Two days before injection and weighing, the fish were starved. Each week for 8 weeks fish either received an injection of $\mathrm{NaCl} 9 \%$ or $\mathrm{NaCl} 9 \%+$ sGH $(0.1 \mu \mathrm{g} / \mathrm{g})$.

\section{Results}

Detection of the fish growth hormone (Fig. 1)

Optic lobe and hypothalamic extracts of all species studied did not cross react in the mammalian radioreceptor assay, the only exception being the hypothalamus of chinook salmon. Conversely, all pituitary extracts displaced bovine $\mathrm{GH}$ from its 


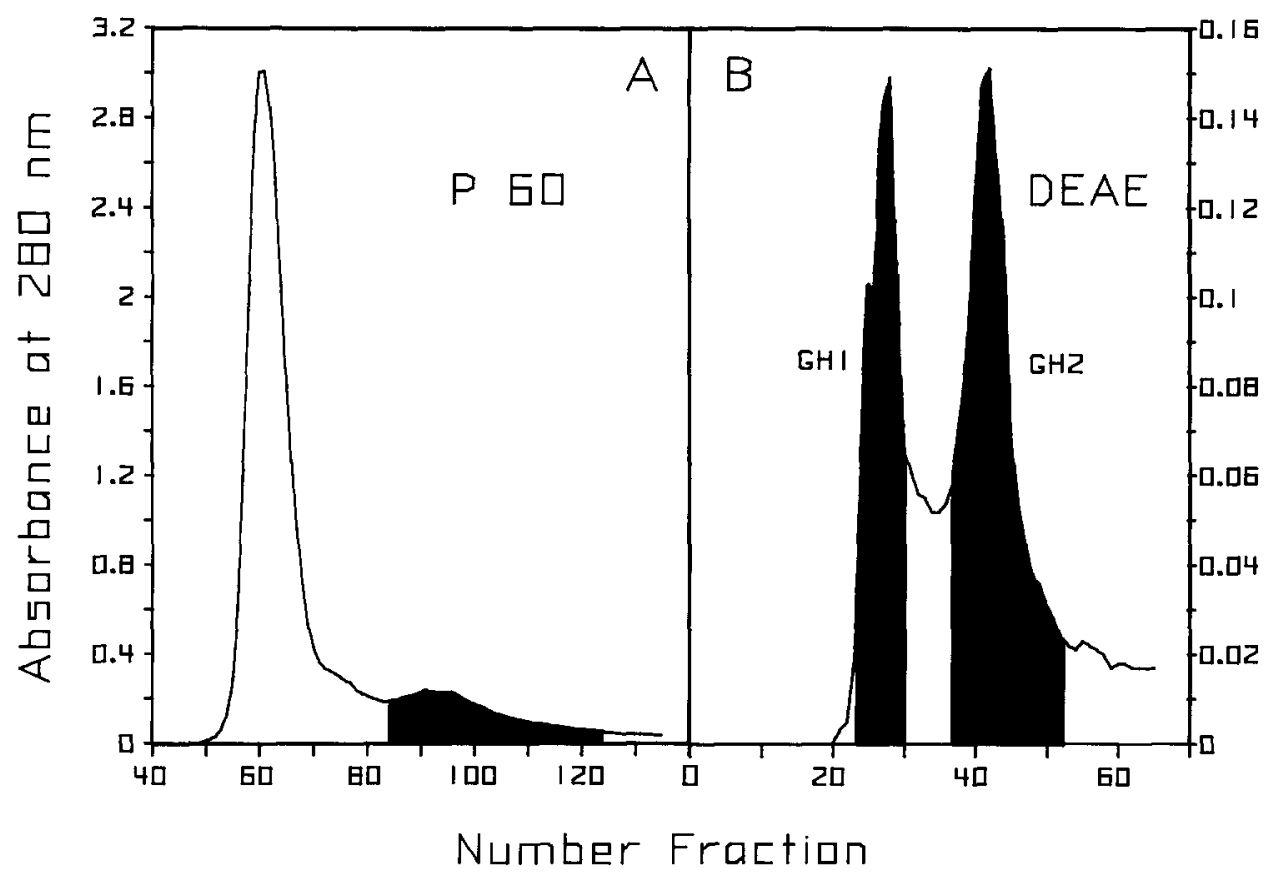

Fig. 2. Chromatography patterns for the purification of sGH. (A) Gel filtration Bio-gel P60 (5 $\times 100 \mathrm{~cm})$ in $100 \mathrm{mM}$ ammonium bicarbonate buffer ( $\mathrm{pH} \mathrm{10}$ ). The second peak (in black) was diluted $5 \mathrm{mM}$, concentrated to $20 \mathrm{ml}$ with an ultrafiltration cell (Amicon Diaflo), then applied to the DEAE column. (B) Ion exchange chromatography of the concentrate on DEAE Trisacryl M $(1,6 \times 50 \mathrm{~cm})$ with $5 \mathrm{mM}$ ammonium bicarbonate buffer $(\mathrm{pH} \mathrm{10})$ and eluted with $20 \mathrm{mM}$ of the same buffer.

receptor. The gradient of the displacement curve was not as steep as that of standard curve of bGH. There was no difference between the gradients of the different fish species.

Using this radioreceptorassay and constant protein concentration, chinook pituitary extract obtained at $\mathrm{pH} 10$ induced the best displacement (range of pH tested: $2-11$; results not shown). An electrophoresis (SDS-PAGE) of this extract, has permitted to estimate at about $8 \%$ (Vernon photometer) the band comigrating with the heaviest bGH band. For this two reasons, this $\mathrm{pH}$ was used for $\mathrm{sGH}$ purification.

\section{Purification}

During the different steps of purification, sGH was identified by electrophoresis (SDS-PAGE).

When the non-glycoprotein fraction from Con-A was analysed chromatographically, using P60 gel, the void volume showed as a very large first peak (Fig. 2A). The second peak contained proteins
Table I. Recovery yield at the different steps of sGH purification.

\begin{tabular}{|c|c|c|}
\hline Steps & $\%$ recovery & Technique used \\
\hline Lyophilized pituitaries & 100 & Lyophilized weight \\
\hline Alkaline extract & 48 & Lowry et al. (1951) \\
\hline Non glycoproteins & 24 & Lowry et al. (1951) \\
\hline Proteins $<30,000$ dalton & 3.1 & Lowry et al. (1951) \\
\hline \multirow[t]{2}{*}{ Purified sGH } & 0.36 & Lyophilized weight \\
\hline & 0.34 & Lyophilized weight \\
\hline
\end{tabular}

having a MW between 30,000 and 10,000 daltons. The second peak corresponded to about $3 \%$ of the original lyophilized pituitary weight and displayed two distinct peaks using isocratic chromatography on DEAE (Fig. 2B) corresponding to $\mathrm{sGH}_{1}$ and $\mathrm{sGH}_{2}$, respectively. The yield of purification is $0.7 \%$ (Table 1 ).

\section{Characterisation}

With electrophoresis and after denaturation by 


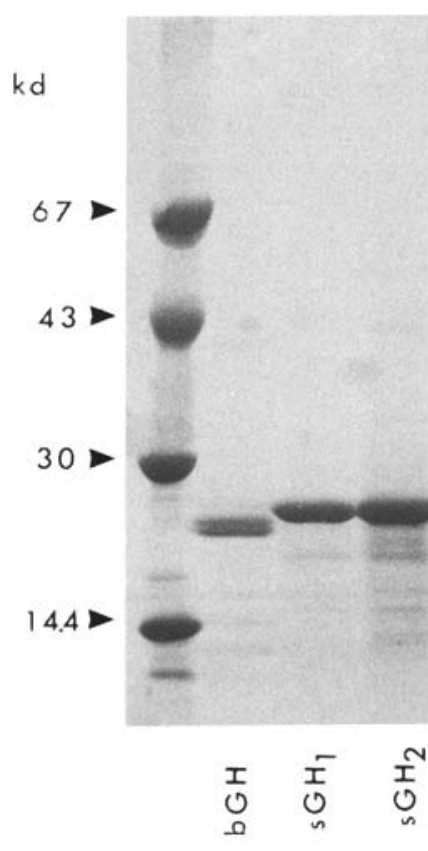

B

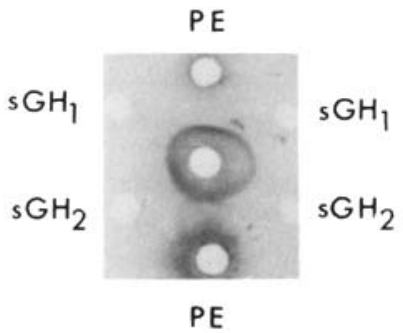

Fig. 3. (A) - Gel electrophoresis (SDS-PAGE) patterns of s-GH. (B) - Immunodiffusion of $\mathrm{sGH}_{1}, \mathrm{sGH}_{2}$ and pituitary extract (PE) against an antiserum raised in rabbit to $\mathrm{sGH}_{2}$.

mercaptoethanol, $\mathrm{sGH}_{1}$ and $\mathrm{sGH}_{2}$ had the same profile (Fig. 3A). The major band migrated with the heaviest $\mathrm{bGH}$ band and corresponded to the monomeric sGH. The minor bands had a MW between 24,000 and 14,000 daltons.

To test whether the minor bands were contaminants, $\mathrm{sGH}_{2}$ was chromatography on a HPLC TSK 2000 column (Fig. 4A). The largest peak, when concentrated and rechromatographed in the same conditions, showed eluent peaks at the same level as those obtained after the first chromatography

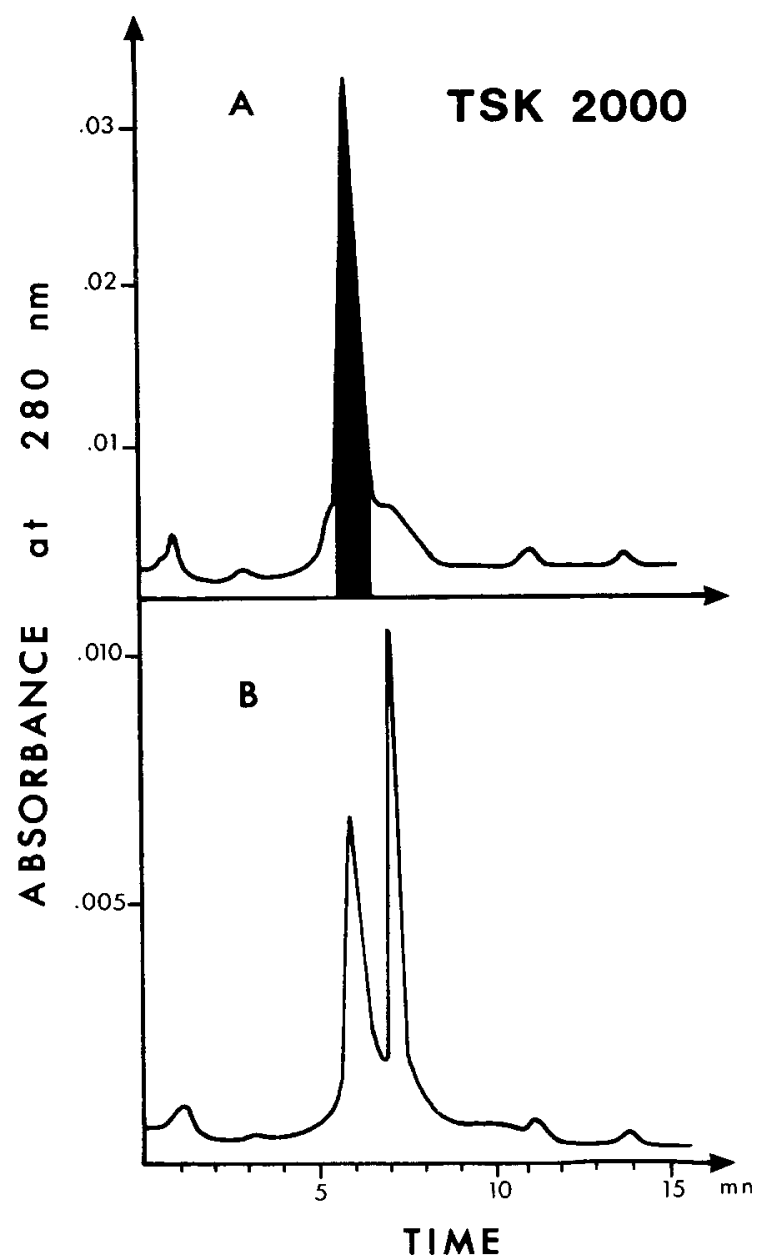

Fig. 4. Homogeneity of sGH. (A) Analytical chromatography was done on HPLC TSK 2000 column $(0.75 \times 60 \mathrm{~cm})$ with 200 $\mathrm{mM}$ phosphate buffer $\mathrm{pH} 7.5$ with a flow rate of $0.5 \mathrm{ml} / \mathrm{min}$. After concentration, the major peak (in black) was applied for a second time on the same column under the same elution conditions (B).

(Fig. 4B). Two of them were dominant, the heaviest form corresponding to the major peak of the first chromatography.

Immunodiffusion studies (Fig. 3B) showed that the $\mathrm{sGH}_{1}$ and $\mathrm{sGH}_{2}$ were immunologically identical, the precipitation arcs being perfectly continuous.

\section{Purity}

By using radioimmunoassays for different pituitary 


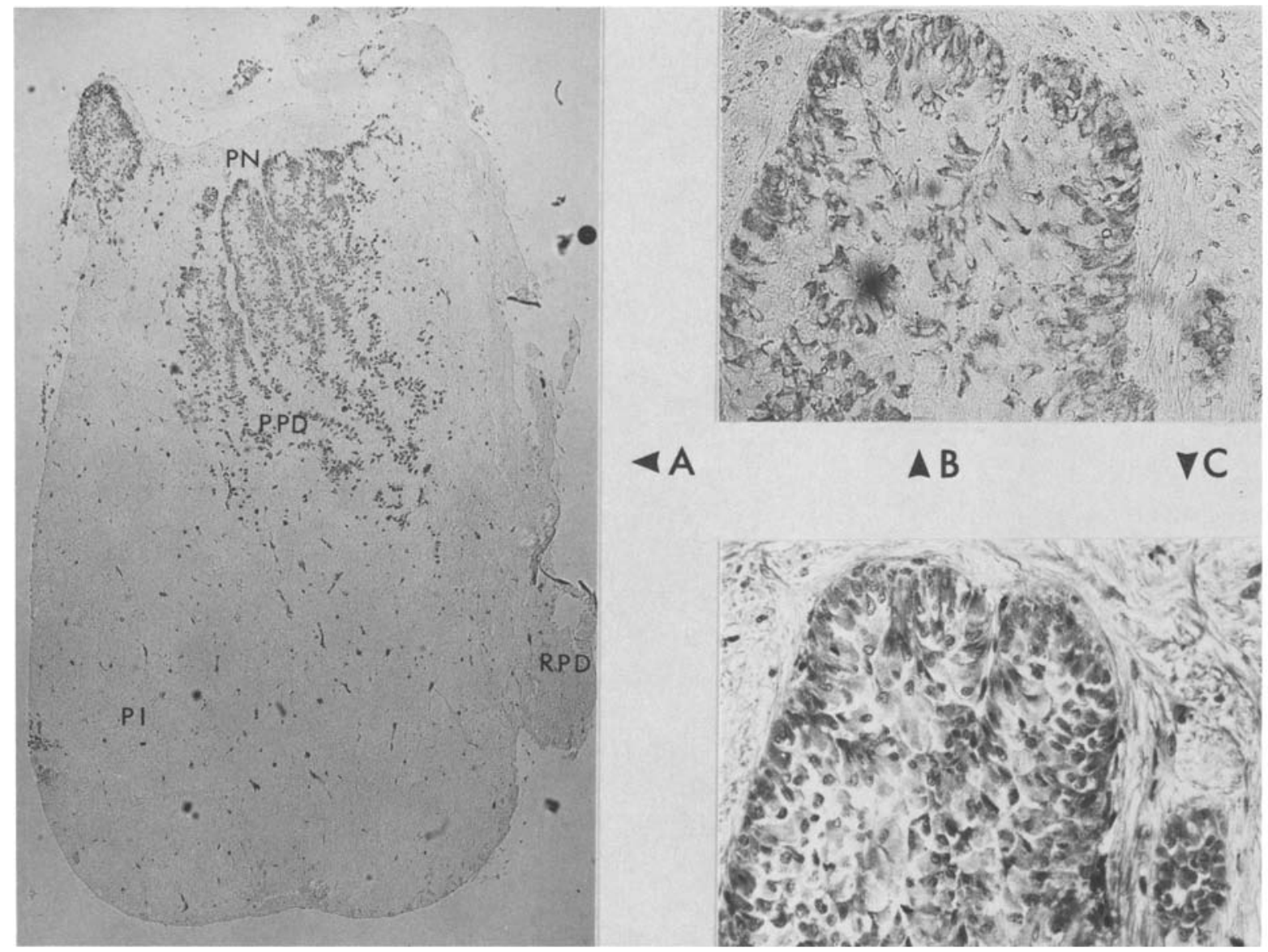

Fig. 5. Sagittal section of rainbow trout pituitary labelled with anti-chinook $\mathrm{GH}_{2}$ rabbit serum (7302 F) at a dilution of $1 / 100$. (A) RPD: rostral pars distalis, PPD: proximal pars distalis, PI: pars intermedia, PN: pars nervosa, $(\times 30)$.

Adjacent sections of PPD were labelled with anti $\mathrm{sGH}_{2}(7302 \mathrm{~F})(\mathrm{B})$ or stained using Cleveland Wolf method (somatotroph cells appear in black) (C).

hormones which were available for salmonids, it was estimated that contamination of the $\mathrm{sGH}_{1}$ and $\mathrm{sGH}_{2}$ respectively were : $\leq 0.2 \%$ and $\leq 0.06 \%$ for prolactin, $\leq 0.4 \%$ and $\leq 0.3 \%$ for gonadotrophin. ACTH contamination was only estimated for $\mathrm{sGH}_{2}$ and this was undetectable, that is to say < $0.01 \%$.

In immunocytochemical studies, a low dilution $(1 / 100)$ of anti $\mathrm{sGH}_{2}$ was used to show up any cross reactivity. The antibody did not bind to either the prolactin cells in the rostral pars distalis, or cells in the pars intermedia (Fig. 5A). In the proximal pars distalis, the anti $\mathrm{sGH}_{2}$ binds only to the cell types (Fig. 5B) which showed up as orange (dark grey in the photography) using the Cleveland Wolf technique (Fig. 5C). These were found very specifically along the pars nervosa ramifications.

\section{Biological activity}

The effect of sGH on the growth of intact juvenile trout is shown in Fig. 6A. Weekly injections of sGH $(0.1 \mu \mathrm{g} / \mathrm{g}$ of live weight) induced an increased growth rate, which after 8 weeks was $61 \%$ greater compared to controls.

Lyophilised $\mathrm{sGH}_{2}$ was soluble in phosphate buffer and $70 \%$ of the iodine linked with the hormone. After incubation for $24 \mathrm{~h}$ at room temperature, the labelled $\mathrm{sGH}_{2}$ showed a total binding of 


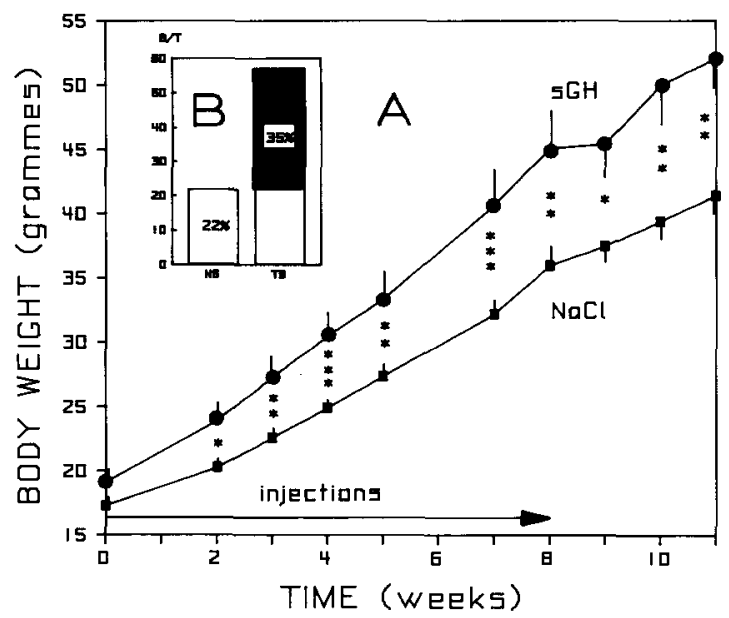

Fig. 6. Biological activity of sGH. (A) Effects of sGH on the growth of juvenile rainbow trout. Fish received one intraperitoneal injection each week at a dose of $0.1 \mu \mathrm{g} / \mathrm{g}$ of body weight during 2 months. Vertical lines represent the standard error of mean. Significant differences from controls (Student's ttest) are as follows: ${ }^{*}(0.05),{ }^{* *}(0.01),{ }^{* * *}(0.005)$. (B) Binding of 125I labelled SGH to trout liver membrane in excess expressed as a percentage of the total radioactivity. Specific binding (black bar) was determined by subtracting the nonspecific binding (NS $={ }^{125} \mathrm{I}$ bound in the presence of $1 \mu \mathrm{g}$ of unlabelled $\mathrm{sGH}$ ) from the total binding $(\mathrm{TB})$.

$57 \%$ with excess trout liver membranes (Fig. 6B). Non-specific binding appears relatively elevated $(22 \%)$ but specific binding is much greater $(35 \%)$.

\section{Discussion}

Fryer (1979) was the first to use a tilapia hepatic radioreceptor assay to evaluate the biological activity of teleostean $\mathrm{GH}$; such an assay requires a source of purified tilapia GH. In this study we applied a method developed for mammals using bovine GH (bGH) which is readily available. The pituitary extracts from all the species tested (salmoniformes, cypriformes, siluriformes and perciformes) specifically displaced bGH from its receptor which suggests that this bioassay is applicable to all teleosts. Contrary to the other species for which the extracts were taken from fresh tissue, the hypothalamic extracts from chinook salmon came from lyophilized tissue in which pituitary material may have been present. This could explain the displace- ment obtained. The affinity of fish $\mathrm{GH}$ for rabbit receptors is weaker than that of bGH. This explains the loss of sensitivity of this technique and the impossibility to follow the increase in biological activity at the different purification steps. However, this technique allows to determine the best conditions of extraction of biologically active $\mathrm{GH}$ from pituitaries of different teleost species.

Before using the purification procedure presented in this article, preliminary investigations using other techniques such as precipitation, hydrophobic chromatography and coloured gel were studied, during which the $\mathrm{GH}$ became insoluble. Ionic strengths used in these experiments were high ( $>$ $500 \mathrm{mM}$ ). As a results of these findings, subsequent experiments were carried out systematically at an alkaline $\mathrm{pH}$, with buffer concentrations not exceeding $100 \mathrm{mM}$. This enabled a totally soluble GH to be obtained with a purification yield (approximately $7 \mathrm{mg} / 10 \mathrm{~g}$ fresh pituitaries) greatly higher than that found by Wagner et al. (1986) and equivalent to that obtained by Kawauchi et al. (1986).

In opposition to the findings of Kawauchi et al. (1986), we were unable to establish any hydrophobic properties of the $\mathrm{sGH}$. This may be due to the fact that there are differences in the primary structures of the $\mathrm{GH}$ of chum and chinook salmon. However the aminoacid sequence of the GHs of 3 salmonid species (Kawauchi et al. 1986; Agellon and Chen 1986; Nicoll et al. 1987), show that there is no difference between rainbow trout $\mathrm{GH}$ and chum salmon $\mathrm{GH}$ and the degree of homogeneity with the coho salmon is $97 \%$. Thus, it seems that the hydrophobic or hydrophilic properties depend on the conditions of extraction and purification. It is evident however that the $\mathrm{sGH}$ is unstable as demonstrated by the effect of a simple HPLC rechromatography after concentration of the fractions. Similarly after electrophoresis (SDS-PAGE) of heavily loaded gels ( $c a 100 \mu \mathrm{g} \mathrm{sGH}$ ) several minor bands are seen in addition to the principal one. These are not due to contamination as the latter is negligible for gonadotrophin, prolactin and for molecules from the corticotrophin family. Using the less sensitive technique of immunoblotting (sensitive at 50ng) no TSH contamination was detected ( $<5 \%$ ) (Swanson, personal communication). 
These forms could be due to a modification of the tertiary molecular structure (HPLC) or to a break in the polypeptidic chain (SDS-PAGE). Further, a low concentration of anti $\mathrm{sGH}_{2}$ applied on histological sections of the trout pituitaries binds to only one cell type localized in the proximal pars distalis. The acidophil cells (stained by orange $G$ ) in proximal pars distalis are considered to be $\mathrm{GH}$ cells in mammals (Gabe 1968; Dubois and Herlant 1968) and also in fish (Ball 1965; Olivereau 1970; Wagner and McKeown 1983; Farbridge et al. 1985). Electron microscopy demonstrates that this antibody only binds to GH cell secretory granules (Dubourg, Kah and Le Bail, unpublished data). These results confirm that the chinook GH that was isolated is extremely pure.

With ion exchange chromatography, chinook salmon $\mathrm{GH}$ appeared as 2 forms, called $\mathrm{sGH}_{1}$ and $\mathrm{sGH}_{2}$ with respect to their elution speed. Their electrical charges are thus different. However, the MW estimated with electrophoresis is the same (23,000 daltons) and it was not possible to distinguish them immunologically. These two forms with a different electrical charge were also observed in the chum salmon (Wagner et al. 1985; Kawauchi et al. 1986). Equal amounts of $\mathrm{sGH}_{1}$ and $\mathrm{sGH}_{2}$ were purified from the same pituitaries. These two forms synthesized in the pituitary could be two genetic variations resulting from the duplication of the salmonid genome (Kawauchi et al. 1986).

Two techniques have been used to characterize the biological activity of the salmonid GH. In this study intraperitoneal injection of $\mathrm{sGH}$ in juvenile trout resulted in an appreciable weight gain $(+61 \%)$, greater than that obtained by Wagner $e t$ al. (1985), but less than that obtained by Kawauchi et al. (1986). However such a comparison is not strictly valid since there are differences in the frequency of injection, quantities administered as well as factors involved in rearing of the fish (exteral factors, strains, etc.) which varied between one experiment and another. Thus it was considered that the percentage of hormone binding to the receptors when they were present in excess is a better indication of biological activity. The best percentage of specific binding ( $36 \%$ presented in our results) was obtained using labelled sGH just after iodination, it is 3 times more than that obtained with tilapia GH by Fryer (1979). This percentage of specific binding decreases with time, and after two weeks it is about $20 \%$ (result not shown). This is the first time that such binding has been established in a homologous system in salmonids, preceding results coming from a tilapia system (Fryer 1979; Fryer and Bern 1979).

The properties of our iodinated sGH and the specificity of our anti sGH suggest that further research could produce a radioimmunoassay system for measurement of circulating levels in salmonids as well as a better understanding of the properties their $\mathrm{GH}$ receptors.

\section{Acknowledgements}

We would like to thank Dr. B. Breton, Dr. P. Prunet, Dr. J. Sumpter and Dr. P. Swanson for performing sGth, sPrl, ACTH and TSH assays, and also to Dr. S. Raiti of the NIH for supplying bovine GH. The authors are grateful to Dr. M. Loir for his comments and criticisms, to C. Cauty and B. Mourot for technical assistance, to Mses J. Hall and H.A. McLay for assistance with translation of the manuscript. These studies were supported by grant from the I.F.R.E.M.E.R.

\section{References cited}

Agellon, L.B. and Chen, T.T. 1986. Rainbow trout growth hormone: molecular cloning of cDNA expression in Escherichia coli DNA 5: 463-471.

Ball, J.N. 1965. Partial hypophysectomy in the teleost Poecilia: separate identities of teleostean growth hormone and teleostean prolactin-like hormone. Gen. Comp. Endocrinol. 5: 654-661.

Bolton, J.P., Takahashi, A., Kawauchi, H., Kubota, J. and Hirano, T. 1986. Development and validation of a salmon growth hormone radioimmunoassay. Gen. Comp. Endocrinol. 62: 230-238.

Breton, B., Prunet, P. and Reinaud, P. 1978. Sexual differences in salmon gonadotropin. Ann. Biol. Anim. Bioch. Biophys. 18: 759-765.

Cook, A.F., Wilson, S.W. and Peter, R.E. 1983. Development and validation of a carp growth hormone radioimmunoassay. Gen. Comp. Endocrinol. 50: 335-347.

Dubois, M.P. and Herlant, M. 1968. Caractères cytologiques des cellules gonadotropes, thyréotropes, corticotropes, 
somatotropes et des cellules à prolactine présentes dans le lobe antérieur de l'hypophyse des bovins. Ann. Biol. Anim. Bioch. Biophys. 8: 5-20.

Farbridge, K.J., Burke, M.G. and Leatherland, J.F. 1985. Seasonal changes in the structure of the adenohypophysis of the brown bullhead (Ictalurus nebulosus). Cytobios 44: 49-66.

Farmer, S.W., Papkoff, H., Hayashida, T., Bewley, T.A., Bern, H.A. and Li, C.H. 1976. Purification and properties of teleost growth hormone. Gen. Comp. Endocrinol. 30: 91-100.

Fryer, J.N. 1979. A radioreceptor assay for purified teleost growth hormone. Gen. Comp. Endocrinol. 39: 123-130.

Fryer, J.N. and Bern, H.A. 1979. Growth hormone binding to tissues of normal and stunted juvenile coho Salmon, (Oncorhynchus kisutch). J. Fish Biol. 15: 527-533.

Gabe, M. 1968. Techniques Histologiques. Masson et Cie, Paris.

Gerasimo, P., Djiane, J. and Kelly, P.A. 1979. Titration of total binding sites for growth hormone in rabbit liver. Quantitative modifications of these sites during pregnancy. Mol. Cell. Endocrinol. 13: 11-23.

Hirano, T., Prunet, P., Kawauchi, H., Takahashi, A., Ogasawara, T., Kubota, J. Nishioka, R.S. Bern, H.A., Takada, K. and Ishii, S. 1985. Development and validation of a Salmon prolactin radioimmunoassay. Gen. Comp. Endocrinol. 59: 266-276.

Kawauchi, H. Moriyama, S., Yasuda, A. Yamaguchi, K., Shirahata, K., Kubota, J. and Hirano, T. 1986. Isolation and characterization of chum salmon growth hormone. Arch. Biochem. Biophys. 244: 542-552.

Kelly, P.A., Leblanc, G. and Djiane, J. 1979. Estimation of total prolactin-binding sites after in vitro desaturation. Endocrinology 104: 1631-1638.

Kishida, M. Hirano, T., Kubota, J., Hasegawa, S., Kawauchi, H., Yamaguchi, K. and Shirahata, K. 1987. Isolation of two forms of growth hormone secreted from eel pituitaries in vitro. Gen. Comp. Endocrinol. 65: 478-488.

Komourdjian, M.P. and Idler, D.R. 1979. Chum salmon pituitary fractions: somatotropic activity and cytoimmunofluorescence studies. Gen. Comp. Endocrinol. 37: 343-349.
Laemmli, U.K. 1970. Cleavage of structural proteins during the assembly of the head of bacteriophage T4. Nature, Lond. 227: 680-685.

Lowry, O.H., Rosebrough, N.J., Lewis Farr, A. and Randall, R.J. 1951. Protein measurement with the folin phenol reagent. J. Biol. Chem. 193: 265-275.

Nicoll, C.S., Steiny, S.S., King, D.S., Nishioka, R.S., Mayer, G.L., Eberhardt, N.L., Baxter, J.D., Yamanaka, M.K., Miller, J.A., Seilhamer, J.J., Schilling, J.W. and Johnson, L.K. 1987. The primary structure of coho salmon growth hormone and its cDNA. Gen. Comp. Endocrinol. 68: 387-399.

Olivereau, M. 1970. Stimulation des cellules somatotropes de l'hypophyse de la carpe après un jeune prolongé. C.R. Acad. Sci. Paris 270: 2343-2346.

Ouchterlony, O. 1967. In Handbook of Experimental Immunology, p. 655. Edited by Weir.

Specker, J.L., King, D.S., Nishioka, R.S., Shizahata, K., Yamaguchi, K. and Bern, H.A. 1985. Isolation and partial characterization of a pair of prolactins released in vitro by the pituitary of a cichlid fish, Oreochromis mossambicus. Proc. Nat. Acad. Sci. U.S.A. 82: 7490-7494.

Sumpter, J.P. and Donaldson, E.M. 1986. The development and validation of a radioimmunoassay to measure plasma ACTH levels in salmonid fishes. Gen. Comp. Endocrinol. 62: 367-376.

Tarpey, J.F. and Nicoll, C.S. 1985. Characterization of hepatic growth hormone binding sites in two fish species, Gillichthys mirabilis (Teleostei) and Acipenser transmontanus (Chondrostei). Gen. Comp. Endocrinol. 60:39-50.

Wagner, G.F. and McKeown, B.A. 1983. The immuno-cytochemical localisation of pituitary somatotrops in the genus Oncorhynchus using an antiserum to growth hormone of chum salmon (Oncorhynchus keta). Cell. Tiss. Res. 231: 693-697.

Wagner, G.F. Fargher, R.C., Brown, J.C. and McKeown, B.A. 1985. Further characterization of growth hormone from the chum salmon (Oncorhynchus keta). Gen. Comp. Endocrinol. 60: 27-34.

Wagner, G.F. and McKeown, B.A. 1986. Development of a salmon growth hormone radioimmunoassay. Gen. Comp. Endocrinol. 62: 452-458. 